\title{
Control Measures of Pathogenic Microorganisms and Shelf-Life Extension of Fresh-Cut Vegetables
}

\author{
Jeong Yeon Lee $\mathbb{D}$, So Young Yang and Ki Sun Yoon*(D) \\ Department of Food and Nutrition, College of Human Ecology, Kyung Hee University, 26 Kyungheedae-ro, \\ Dongdaemun-gu, Seoul 02447, Korea; ljyeon0902@naver.com (J.Y.L.); didthdud5253@naver.com (S.Y.Y.) \\ * Correspondence: ksyoon@khu.ac.kr; Tel.: +82-2-961-0264
}

Citation: Lee, J.Y.; Yang, S.Y.; Yoon, K.S. Control Measures of Pathogenic Microorganisms and Shelf-Life Extension of Fresh-Cut Vegetables. Foods 2021, 10, 655. https://doi.org/ $10.3390 /$ foods 10030655

Academic Editor: Victor Rodov

Received: 14 February 2021

Accepted: 15 March 2021

Published: 19 March 2021

Publisher's Note: MDPI stays neutral with regard to jurisdictional claims in published maps and institutional affiliations.

Copyright: (c) 2021 by the authors. Licensee MDPI, Basel, Switzerland. This article is an open access article distributed under the terms and conditions of the Creative Commons Attribution (CC BY) license (https:/ / creativecommons.org/licenses/by/ $4.0 /)$.

\begin{abstract}
We investigated the combined effect of using slightly acidic electrolyzed water (SAEW), ultrasounds (US), and ultraviolet-C light-emitting diodes (UV-C LED; $275 \mathrm{~nm}$ ) for decreasing pathogenic Escherichia coli and Staphylococcus aureus (SEA) in fresh-cut vegetables, including carrots, celery, paprika, and cabbage. Survival of pathogenic E. coli and SEA and quality properties of fresh-cut vegetables at 5 and $15^{\circ} \mathrm{C}$ for 7 days were also investigated. When combined treatment (SAEW + US + UV-C LED) was applied to fresh-cut vegetables for $3 \mathrm{~min}$, its microbial reduction effect was significantly higher $(0.97 \sim 2.17 \log \mathrm{CFU} / \mathrm{g})$ than a single treatment $(p<0.05)$. Overall, the reduction effect was more significant for SEA than for pathogenic E. coli. At $5{ }^{\circ} \mathrm{C}, \mathrm{SAEW}+\mathrm{US}$ and SAEW + US + UV-C LED treatments reduced populations of pathogenic E. coli and SEA in all vegetables. At $15{ }^{\circ} \mathrm{C}$, SAEW + US + UV-C LED treatment inhibited the growth of both pathogens in carrot and celery and extended the shelf life of fresh-cut vegetables by preventing color changes in all vegetables. Although the effects of treatments varied depending on the characteristics of the vegetables and pathogens, UV-C LED can be suggested as a new hurdle technology in fresh-cut vegetable industry.
\end{abstract}

Keywords: fresh-cut vegetables; slightly acidic electrolyzed water (SAEW); ultrasounds (US); ultraviolet-C light-emitting diodes (UV-C LED); shelf life

\section{Introduction}

Recently, purchase rates for fresh-cut vegetables such as ready-to-eat (RTE) food and meal kits have increased [1,2]. RTE fresh-cut vegetables generally refers to salads and stickshaped and raw cut vegetables. They are generally consumed without washing or heating. They mainly include lettuce, cabbage, carrot, celery, cherry tomatoes, paprika, and so on [1-4]. However, due to non-thermal and minimal processing, contamination by pathogenic bacteria and viruses can be a risk factor during their production and distribution [5].

Foodborne illness outbreaks caused by pathogenic Escherichia coli and Staphylococcus aureus have been constantly occurring in Korea [6]. In the US and Europe, foodborne illness outbreaks at homes and restaurants due to consumption of fresh products contaminated by pathogenic E. coli O157:H7 and E. coli O104:H4 have been reported [7-10]. In addition, $S$. aureus and pathogenic $E$. coli have been consistently detected at high rates in agricultural products and RTE fresh-cut vegetables [11-13]. Recent research has also shown that some pathogens, including L. monocytogenes, E. coli O157:H7, Salmonella spp., S. aureus, B. cereus, and C. jejuni, have been isolated from various fruits and vegetables [14]. Therefore, appropriate measures to minimize contamination of foodborne pathogens and their effective control are required for RTE fresh-cut vegetables.

In general, sodium hypochlorite $(\mathrm{NaClO})$ or a slightly acidic electrolyzed water (SAEW) is used in the washing and disinfection step as a critical control point (CCP) during the processing of fresh-cut vegetables $[15,16]$. Ultrasonic inactivation has been associated with damage to the cell wall and membrane of bacteria. However, it cannot be 
efficiently used in industrial applications because of its poor sterilization effect [17]. In recent studies, combined treatment with ultrasounds and SAEW has been applied, as it shows a synergistic bactericidal effect. Both ultrasounds and SAEW are known as safe, economical, and efficient methods [18,19]. Reduction effects of these disinfection treatments on pathogenic microorganisms in various vegetables have been studied [19-21].

Ultraviolet (UV) refers to light in the wavelength range of $100-400 \mathrm{~nm}$. In this wavelength range, UV-C (200-280 $\mathrm{nm})$ has the highest antibacterial activity [22,23]. Mercurybased UV-C lamps were frequently used for sterilization and disinfection in the past. However, they have been criticized due to mercury leak potential, short light life, and low energy efficiency [22]. As alternatives, semiconductor-based UV light-emitting diodes (LEDs) are attracting attention. LEDs can be developed in various wavelengths depending on the purpose. They also have excellent durability, energy efficiency, safety (not mercury), size, and long light life [24]. Ultraviolet-C light-emitting diodes' (UV-C LED) treatment has been suggested as a new technology to inactivate pathogens $[18,24]$.

UV-C LED treatment is more efficient than UV-A LED treatment $(315-400 \mathrm{~nm}$ ) for decreasing pathogenic microorganisms in various foods [25-28]. However, few studies have applied UV-C LED to vegetables products. In our preliminary study, S. aureus was detected qualitatively in five (5\%) samples among 100 RTE fresh-cut vegetables and mealkit products from online and offline markets. Thus, more efficient control measures than simple washing must be applied to RTE fresh-cut vegetables during processing for the safety of consumers.

Thus, objectives of this study were (1) to evaluate combined effects of using ultrasounds (US), slightly acidic electrolyzed water (SAEW), and ultraviolet-C light-emitting diodes (UV-C LED) on pathogenic E. coli and enterotoxin A-producing S. aureus before packaging step; (2) to extend shelf life of fresh-cut vegetables at retail markets.

\section{Materials and Methods}

\subsection{Bacterial Strains}

Pathogenic Escherichia coli including enteropathogenic E. coli (EPEC; NCCP 13715), enterotoxigenic E. coli (ETEC; NCCP 13717), and enterohemorrhagic E. coli O157:H7 (EHEC; NCTC 12079) producing verotoxins V1 and V2 were obtained from the Ministry of Food and Drug Safety (MFDS). Enterotoxin A-producing Staphylococcus aureus (SEA; ATCC 13565) was purchased from Korean Culture Center of Microorganisms (KCCM, Seoul, Korea). Each stock culture of pathogenic E. coli and S. aureus was maintained at $-80^{\circ} \mathrm{C}$ in tryptic soy broth (TSB, MBcell, Seoul, Korea) containing 20\% glycerol. Frozen stocks were thawed for each experiment. After thawing, $10 \mu \mathrm{L}$ of each strain was inoculated into $10 \mathrm{~mL}$ of sterile TSB and incubated at $36^{\circ} \mathrm{C}$ for $24 \mathrm{~h}$ on a rotary shaker (VS-8480SP, Vision, Korea) at $140 \mathrm{rpm}$. Viable cell counts of pathogenic E. coli and S. aureus at the end of the incubation period ranged from 9.5 to $10.0 \mathrm{log} \mathrm{CFU} / \mathrm{g}$. For a cocktail strain of pathogenic E. coli, each bacterium culture was mixed in equal volumes. For spot-inoculation, $1 \mathrm{~mL}$ of starter culture at stationary phase was transferred into $9 \mathrm{~mL}$ of $0.1 \%$ sterilized peptone water (BD, Sparks, MD, USA) and then serially diluted before inoculation into samples. For dip-inoculation onto cabbage, $1 \mathrm{~L}$ (approximately $7 \log \mathrm{CFU} / \mathrm{g}$ ) of culture was prepared.

\subsection{Preparation of Samples and Inoculation for Inactivation Study}

According to our monitoring study, carrots, celery, paprika, and cabbage are the most common fresh-cut vegetables at a local market (Dongdemun-gu, Seoul, Korea). Each of these four raw vegetables was first washed in running tap water in order to remove soil and dust. After peeling off the outer skin, carrots were cut into stick-shaped pieces of $10 \mathrm{~g}$ each (length of $5 \sim 6 \mathrm{~cm}$ ). After removing the outer two leaves and the core, cabbages were shredded to a thickness of $0.5 \mathrm{~cm}$ to prepare shredded cabbage samples (100 g each). Surfaces of carrots, celery, and paprika (10 g each) were inoculated with $100 \mu \mathrm{L}$ of a three-strain cocktail of pathogenic E. coli and S. aureus producing enterotoxin A (SEA), respectively. Shredded cabbage (100 g) was dipped into $1 \mathrm{~L}$ of pathogenic E. coli and $S$. 
aureus suspensions $(7 \log \mathrm{CFU} / \mathrm{g}$ ) and stirred for $2 \mathrm{~min}$. Initial inoculation levels were approximately 5.5-6 $\log \mathrm{CFU} / \mathrm{g}$. These inoculated samples were air-dried on a sterile stainless tray under a clean bench for $30 \mathrm{~min}$.

\subsection{Microbial Analysis}

To investigate effect of each treatment for reducing the growth of pathogenic bacteria, viable cell count was measured using a spread plate culture method. Following disinfection treatment, $10 \mathrm{~g}$ of each treated sample was homogenized with $90 \mathrm{~mL}$ of sterile $0.1 \%$ peptone water using a stomacher (Interscience, Paris, France). The homogenate was serially diluted ten-fold with $0.1 \%$ peptone water and spread in duplicate onto selective media: eosin methylene blue agar (EMB, MBcell, Seoul, Korea) for pathogenic E. coli and Baird-Parker agar base (BPA, MBcell, Seoul, Korea) supplemented with egg yolk tellurite emulsion (MBcell, Seoul, Korea) for S. aureus. Tryptic soy agar (TSA, MBcell, Seoul, Korea), a nonselective medium, was used for both E. coli and S. aureus. Plates with selective and nonselective media were then incubated at $37^{\circ} \mathrm{C}$ for $24 \sim 48 \mathrm{~h}$. The number of colonies on each plate was then counted. Bacterial counts from duplicate plates were converted to log numbers.

\subsection{Effect of Microbial Reduction with SAEW, US, and UV-C LED before Packaging}

2.4.1. Slightly Acidic Electrolyzed Water (SAEW) Treatment

Slightly acidic electrolyzed water (SAEW) at $30 \mathrm{ppm}$ was produced using a SAEW generator (BC-120, Cosmic Round Korea Co., Seongnam, Korea) that basically consisted of a non-membrane electrolytic chamber with anode and cathode electrodes. The $\mathrm{pH}$ and available chlorine concentration of SAEW were measured with a $\mathrm{pH}$ meter (Orion-star $\mathrm{pH}$ Bechtop, Thermo, USA) and a chlorine test paper (Toyo Roshi Kaisha, Ltd., Toyo, Japan), respectively, before SAEW was used to treat samples. The $\mathrm{pH}$ and available chlorine concentration of SAEW were 5.5 and $30 \mathrm{ppm}$, respectively.

\subsubsection{Ultrasound (US) Treatment}

Ultrasound (US) treatment was performed using a sterile bench-top ultrasonic cleaner (POWERSONIC 620, Hwashin Tech Co., Ltd., Gyeonggi-do, Korea) at a fixed frequency of $40 \mathrm{kHz}$ and an ultrasonic power of $700 \mathrm{~W}$. After an ultrasound device (rectangular tank, $500 \times 300 \times 150 \mathrm{~mm})$ was filled with $4 \mathrm{~L}$ of tap water, a stainless container $(280 \times 215 \times$ $140 \mathrm{~mm}$ ) was placed in this device and filled with SAEW prior to experiment. Ten samples $(100 \mathrm{~g})$ were immersed in SAEW.

\subsubsection{Combined Washing Treatment with SAEW and US}

In order to investigate the optimal conditions of combined washing treatment with SAEW and US, the reduction effect of combined treatment was tested with carrot contaminated with EPEC alone under the following experimental conditions: time ( 0 and $3 \mathrm{~min})$, the temperature of treatment solution $\left(25\right.$ and $40^{\circ} \mathrm{C}$ ), and solution volume (10 and 20 times) with referring the previous works $[21,29]$. Carrots inoculated with EPEC were placed in a sterile stainless container filled with one or two liters of SAEW along with the ultrasound device. Reduction effects of EPEC in carrot under various conditions were compared as mentioned above. After treatments, samples were air-dried under a clean bench for $30 \mathrm{~min}$. The most efficient reduction was observed for samples washed with SAEW for $3 \mathrm{~min}$ at ten times the sample volume in this preliminary work (Table 1). Thus, all fresh-cut vegetable samples (carrot, celery, paprika, and cabbage) were inoculated with pathogenic E. coli and S. aureus (SEA), respectively. They were treated in the same way. 
Table 1. Application conditions of single or combined treatments with SAEW, US, and UV-C LED applied for fresh-cut vegetables.

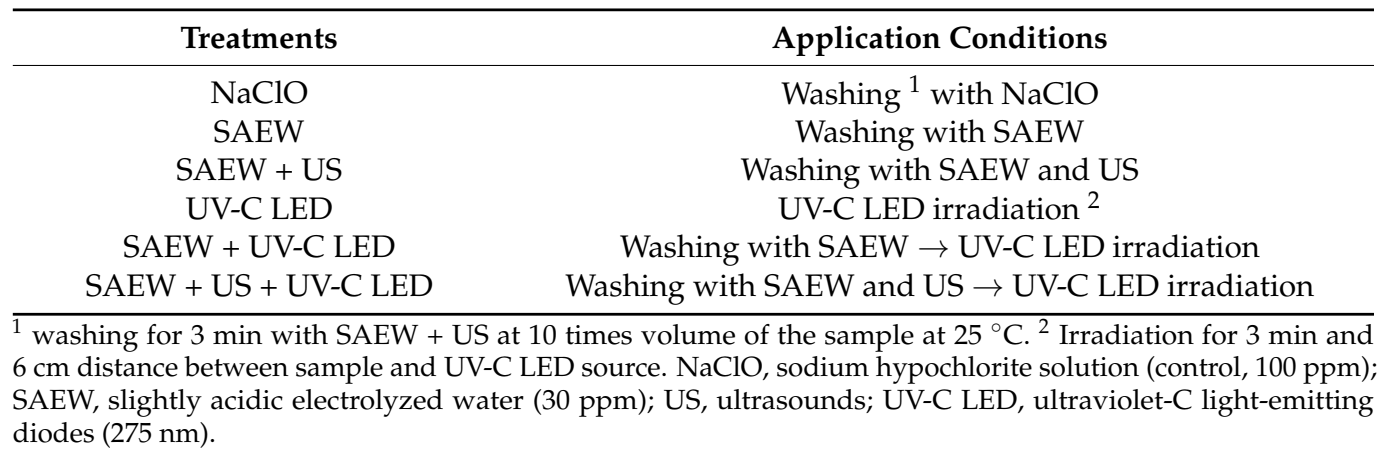

\subsubsection{Treatment with Ultraviolet-C Light-Emitting Diodes (UV-C LED)}

Five ultraviolet-C light-emitting diodes (UV-C LED, $275 \mathrm{~nm}$ ) modules (Seoulviosys Co., Ltd., Gyeonggi-do, Korea) were connected onto bar-type electronic printed circuit boards (PCBs) of $45 \mathrm{~cm}$ in length. Direct current voltage (500 mA) from a power supply (TY-1006, Tae Young Electronics Co., Ltd., Gyeonggi-do, Korea) was applied to PCBs. UV-C LED treatment was performed in a chamber $(500 \times 400 \times 520 \mathrm{~mm})$ equipped with two PCBs. The UV-C radiation intensity of UV-C LEDs was measured with a UV light meter (UVC-254SD, Lutron Electronics Co., Inc., Coopersburg, PA, USA) calibrated for a range of $240 \sim 390 \mathrm{~nm}$. It was measured to be $23 \mu \mathrm{W} / \mathrm{cm}^{2}$.

To determine optimum irradiation conditions (processing time: 1 and $3 \mathrm{~min}$; distance between sample and UV-C LED: 6 and $14 \mathrm{~cm}$ ), effects of UV-C LED for reducing pathogenic bacteria were compared at each condition with two PCBs. The effect of microbial reduction was first tested for carrots and celeries contaminated with a three-strain cocktail of pathogenic E. coli. The superior performance of UV-C LED treatment was observed with an exposure time of $3 \mathrm{~min}$ and a distance between sample and UV-C LED source of $6 \mathrm{~cm}$ in this work (Figure 1). Then, prewashed and dried fresh-cut vegetables (carrot, celery, paprika, and cabbage, $10 \mathrm{~g}$ each) were inoculated with the three-strain cocktail of pathogenic E. coli and S. aureus (SEA), respectively, and then transferred to polyethylene terephthalate (PET) containers. They were placed in the chamber. The distance between each sample and the UV-C LED source was $6 \mathrm{~cm}$. Samples were then irradiated with UV-C LED for $3 \mathrm{~min}$. The UV-C dose at this condition was $4.14 \mathrm{~mJ} / \mathrm{cm}^{2}$.

\subsubsection{Combined Treatment with SAEW, US, and UV-C LED}

To evaluate the combined effect, combined treatment with SAEW, US, and UV-C LED was carried out in this study using conditions shown in Table 1. As a positive control, 100 ppm of sodium hypochlorite ( $\mathrm{NaClO}$; Hanson Hygiene Co., Chungcheongnam-do, Korea) solution was used. This solution was prepared by diluting $4 \% \mathrm{NaClO}$ solution using distilled water.

\subsection{Quality Evaluation for Treated Vegetables during Storage at 5 and $15^{\circ} \mathrm{C}$ after Packaging}

To evaluate qualities of fresh-cut vegetables, carrot, celery, paprika, and cabbage were treated with SAEW + US or SAEW + US + UV-C LED irradiation. Treated samples were packaged with PET containers (Modenpack, Seoul, Korea) and then stored at $5{ }^{\circ} \mathrm{C}$ (storage temperature) and $15{ }^{\circ} \mathrm{C}$ (abused temperature) for 7 days.

2.5.1. Survival of Pathogenic E. coli and S. aureus on Fresh-Cut Vegetables after Combined Treatment

For fresh-cut vegetables inoculated with pathogenic E. coli and S. aureus, survival rates of these pathogens after treatments during storage were investigated and compared with those in the control group without any treatment. This experiment was repeated twice at different time. 


\subsubsection{Effects of Combined Treatments on Quality Parameters of Fresh-Cut Vegetables}

To investigate effects of applied treatments on physical qualities of fresh-cut vegetables, moisture loss, instrumental color, and appearance observation were measured. Moisture loss was determined by taking the difference between the initial weight of treated fresh-cut vegetable and that obtained one at the end of each storage time using the following formula:

$$
(\%) \text { Moisture loss }=(\text { initial mass }- \text { final mass }) \div \text { initial mass } \times 100
$$

The color of each sample was measured using a colorimeter (Minolta CR-400, Osaka, Japan) every day for 7 days. The instrument was standardized against a white standardization plate before each measurement. All measurements were performed in triplicate. Color was described as coordinates: lightness $\left(L^{*}\right)$, redness $\left(a^{*}, \pm\right.$ red-green $)$, and yellowness $\left(b^{*}, \pm\right.$ yellow-blue).

\subsection{Statistical Analysis}

Experiments for US, SAEW, and UV-C LED treatments were repeated twice with three replicates per treatment. All statistical analyses were conducted with the Statistical Analysis System SAS V 9.4 (SAS Institute Inc., Cary, NC, USA). The significance of differences among or between samples was determined by one-way ANOVA followed by Duncan's test for multiple range tests or $t$-test at $p<0.05$.

\section{Results and Discussion}

\subsection{Effect of Microbial Reduction with SAEW, US, and UV-C LED before Packaging}

3.1.1. Effects of Volume and Temperature of Combined Treatment with SAEW and US

First of all, reduction effects of combined treatments on EPEC in carrots were compared under various conditions (temperature 25 and $40^{\circ} \mathrm{C}$ and volume of treatment solution 10 and 20 times) as described previously [21,29]. Microbial reduction effects of combined treatments were not significantly different regardless of temperature or volume of washing solution $(p<0.05)$ (Table 2). Previous studies have reported that higher temperature of treatment solution $\left(25 \sim 60{ }^{\circ} \mathrm{C}\right)$ is more effective for reducing pathogenic bacteria in freshcut carrot, potato, and bell pepper $[21,29,30]$. However, potatoes washed at $60^{\circ} \mathrm{C}$ with US treatment have shown color changes [29]. Other studies have reported that dipping in electrolyzed water for $3 \mathrm{~min}$ has the best sanitizing effect [31-33]. The present study also showed that washing for 3 min with SAEW + US at 10 times the sample volume at $25^{\circ} \mathrm{C}$ was the most effective treatment condition to reduce the population of EPEC in fresh-cut carrot. Ultrasonic inactivation has been associated with damage to the cell wall and membrane of bacteria. Ultrasound can enhance the inactivation of microorganisms in chemical solutions such as SAEW $[20,34,35]$.

Table 2. Effects of volume and temperature on pathogenic E. coli (EPEC) population in fresh-cut carrot by combined treatment with SAEW and US for $3 \mathrm{~min}$.

\begin{tabular}{ccc}
\hline \multirow{2}{*}{ Volume of SAEW ${ }^{\mathbf{1}}$} & \multicolumn{2}{c}{ Log Reduction $(\boldsymbol{l o g}$ CFU/g) } \\
\cline { 2 - 3 } & $\mathbf{2 5}{ }^{\circ} \mathbf{C}^{\mathbf{2}}$ & $\mathbf{4 0}{ }^{\circ} \mathbf{C}$ \\
\hline 10 times & $1.15 \pm 0.15^{3}$ & $1.04 \pm 0.08$ \\
20 times & $1.02 \pm 0.06$ & $* 1.31 \pm 0.06^{* *}$ \\
\hline
\end{tabular}

${ }^{1}$ The volume of SAEW was a multiple of the sample volume. ${ }^{2}$ The temperature of SAEW. ${ }^{3}$ The data were obtained from a non-selective media. * Significant difference between the volume of SAEW was observed at each temperature $(p<0.05) .{ }^{* *}$ Significant difference between the temperature of SAEW was observed at each volume $(p<0.05)$.

\subsubsection{Effects of Time and Distance between Sample and UV-C LED source}

To determine optimum irradiation conditions such as application time (1 and $3 \mathrm{~min})$ and distance between a sample and UV-C LED ( 6 and $14 \mathrm{~cm})$, reduction effects of UV-C LED were compared with pathogenic E. coli cocktail strains in carrot and celery at different conditions. 
The highest reduction was observed for both carrot and celery after UV-C irradiation for 3 min with a distance of $6 \mathrm{~cm}$ (Figure 1). Thus, this was confirmed as the optimal condition under the present UV-C irradiation dose $\left(4.14 \mathrm{~mJ} / \mathrm{cm}^{2}\right)$. Reduction levels of E. coli O157:H7, $S$. Typhimurium, and L. monocytogenes in culture media under UV-C (266 279 nm) dose of $1.67 \sim 3 \mathrm{~mJ} / \mathrm{cm}^{2}$ have been reported to be 3 6 log CFU/g in previous works [36].

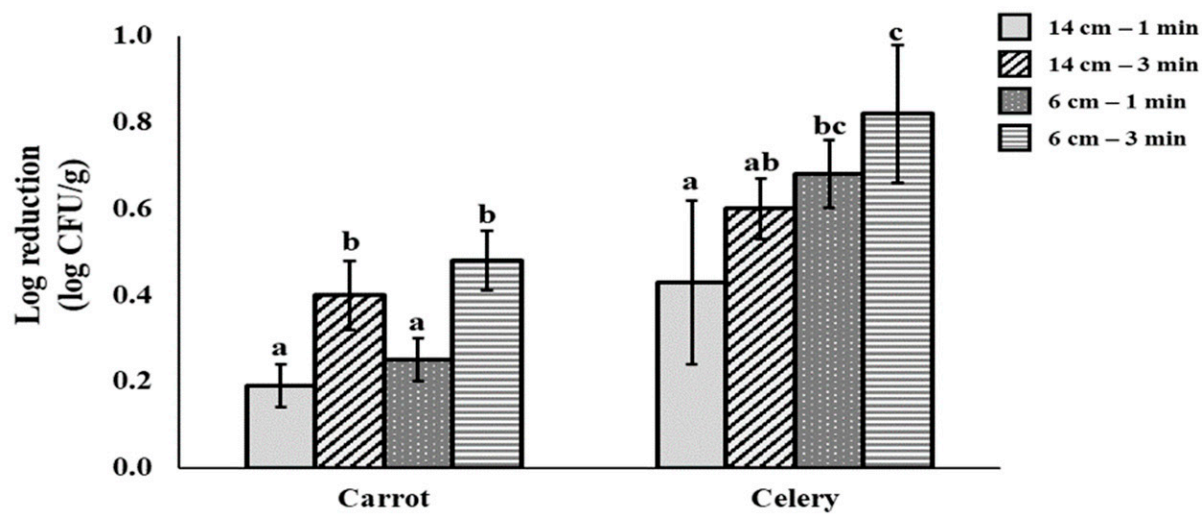

Figure 1. Reduction effect of UV-C LED irradiation $(275 \mathrm{~nm})$ for pathogenic E. coli (cocktail of EPEC, ETEC, and E. coli O157:H7) in fresh-cut carrot and celery at the various conditions. Distances of 6 and $14 \mathrm{~cm}$, distance between the lights and samples; 1 and $3 \mathrm{~min}$, irradiation time. The data were obtained from a non-selective media. ${ }^{\mathrm{a}-\mathrm{c}}$ Values represent significant difference by Duncan's multiple range test at $p<0.05$.

3.1.3. Effect of Microbial Reduction in Combined Treatments with SAEW, US, and UV-C LED before Packaging

Finally, synergistic effects of combined treatments were evaluated to reduce pathogenic E. coli and S. aureus (SEA) in carrot, celery, paprika, and cabbage at the optimal condition of the present study, as shown in Table 3. Results revealed that the combined treatment of 30 ppm SAEW + US (0.61 1.84 log CFU/g reduction) had a greater washing effect than a single treatment by 30 ppm SAEW (0.49 1.39 log CFU/g reduction) for both pathogenic E. coli and S. aureus (SEA) in all vegetables. Additionally, application of UV-C LED irradiation as a pre-packaging step after washing with SAEW or SAEW + US increased the reduction effect compared to UV-C LED irradiation only. Combined treatment of 30 ppm SAEW + US + UV-C LED show higher reduction effect than 100 ppm $\mathrm{NaClO}$ solution alone, indicating that UV-C LED could be used as a new hurdle technology in the industry of fresh-cut vegetables. Regardless of the kind of pathogen, the highest reduction was observed with SAEW + US + UV-C LED (0.97 2.17 log CFU/g) for all four vegetable samples.

Table 3. Reduction populations of pathogenic E. coli (cocktail of EPEC, ETEC, and E. coli O157:H7) and S. aureus (SEA) in various fresh-cut vegetables by disinfection treatments.

\begin{tabular}{|c|c|c|c|c|c|c|c|c|}
\hline \multirow{3}{*}{ Treatments } & \multicolumn{8}{|c|}{ Log Reduction $(\log$ CFU/g) } \\
\hline & \multicolumn{2}{|c|}{ Carrot } & \multicolumn{2}{|c|}{ Celery } & \multicolumn{2}{|c|}{ Cabbage } & \multicolumn{2}{|c|}{ Paprika } \\
\hline & E. coli & S. aureus & E. coli & S. aureus & E. coli & S. aureus & E. coli & S. aureus \\
\hline $\mathrm{NaClO}$ & $* 1.30 \pm 0.19 \mathrm{AB}$ & $0.93 \pm 0.18^{\mathrm{D}}$ & $1.34 \pm 0.52 \mathrm{AB}$ & $1.70 \pm 0.38^{\mathrm{AB}}$ & $0.90 \pm 0.03^{\mathrm{C}}$ & $0.81 \pm 0.09^{\mathrm{B}}$ & $* 1.15 \pm 0.04^{\mathrm{A}}$ & $0.58 \pm 0.18^{\mathrm{BC}}$ \\
\hline SAEW & $0.67 \pm 0.13^{C}$ & $* 1.39 \pm 0.27^{\mathrm{C}}$ & $0.58 \pm 0.12^{C}$ & $0.76 \pm 0.18^{\mathrm{D}}$ & ${ }^{*} 0.68 \pm 0.05^{\mathrm{D}}$ & $0.49 \pm 0.04^{C}$ & $0.54 \pm 0.08^{\mathrm{D}}$ & $0.50 \pm 0.02^{C}$ \\
\hline SAEW + US & $1.09 \pm 0.22^{\mathrm{B}}$ & $* 1.84 \pm 0.24^{\mathrm{B}}$ & $0.83 \pm 0.12^{\mathrm{BC}}$ & $1.11 \pm 0.47^{\mathrm{BC}}$ & $0.77 \pm 0.09^{\mathrm{D}}$ & $0.77 \pm 0.09^{\mathrm{B}}$ & $0.61 \pm 0.16^{\mathrm{D}}$ & $0.67 \pm 0.08^{\mathrm{BC}}$ \\
\hline UV-C LED & $0.48 \pm 0.07^{C}$ & $* 0.76 \pm 0.11^{\mathrm{D}}$ & $0.82 \pm 0.13^{\mathrm{BC}}$ & $* 1.37 \pm 0.31 \mathrm{AC}$ & $0.30 \pm 0.08^{\mathrm{E}}$ & $0.34 \pm 0.21^{\mathrm{D}}$ & $0.41 \pm 0.08^{\mathrm{E}}$ & ${ }^{*} 0.57 \pm 0.06^{\mathrm{BC}}$ \\
\hline SAEW + UV-C LED & $1.10 \pm 0.17^{\mathrm{B}}$ & $* 1.54 \pm 0.27^{\mathrm{C}}$ & $1.04 \pm 0.27^{\mathrm{BC}}$ & $1.60 \pm 0.48^{\mathrm{ABC}}$ & $* 1.13 \pm 0.14^{\mathrm{B}}$ & $0.75 \pm 0.09^{\mathrm{B}}$ & $0.85 \pm 0.10^{\mathrm{C}}$ & $0.74 \pm 0.12^{\mathrm{B}}$ \\
\hline $\begin{array}{c}\text { SAEW + US + UV-C } \\
\text { LED }\end{array}$ & $1.48 \pm 0.20^{\mathrm{A}}$ & $* 2.17 \pm 0.27^{\mathrm{A}}$ & $1.59 \pm 0.21^{\mathrm{A}}$ & $2.02 \pm 0.44^{\mathrm{A}}$ & $* 1.27 \pm 0.09 \mathrm{~A}$ & $0.97 \pm 0.05^{\mathrm{A}}$ & $0.97 \pm 0.06^{\mathrm{B}}$ & $1.20 \pm 0.26^{\mathrm{A}}$ \\
\hline
\end{tabular}

$\mathrm{NaClO}$, sodium hypochlorite solution (control, 100 ppm); SAEW, slightly acidic electrolyzed water (30 ppm); US, ultrasounds; UV-C LED, ultraviolet-C light-emitting diodes $(275 \mathrm{~nm})$. The data were obtained from a non-selective media. A-E Within the same column, values not followed by the same uppercase letter are significantly different $(p<0.05)$. * Significant difference between E. coli and S. aureus was observed at each vegetable $(p<0.05)$. 
Combined washing with SAEW and US has been reported to be effective for microbial decontamination and shelf life extension of various vegetables [21,37-39] and kashk [40]. Reduction levels of E. coli O157:H7 have been observed to be 1.3 3.3 log CFU/g in Chinese cabbage, lettuce, sesame leaf, spinach, and kale after washing with SAEW and US [37,39]. Combined washing with SAEW and US for kashk has also shown a reduction effect of $1.7 \log \mathrm{CFU} / \mathrm{g}$ for E. coli O157:H7 and $1.9 \log \mathrm{CFU} / \mathrm{g}$ for S. aureus [40]. Maximum reduction effect of washing with SAEW and US for B. cereus biofilms has been reported to be 4 log $\mathrm{CFU} / \mathrm{g}$ on leafy green vegetables [38]. In our study, a combined washing treatment with 30 ppm SAEW and US showed similar reduction levels as those shown in other studies.

Recent studies have reported reduction effects of UV-C LED irradiation $(254 \sim 280 \mathrm{~nm}$ wavelength) on apple juice and apple [26,27]. Jiang et al. [28] have also investigated the effect of combined treatment with SAEW and UV-C LED for inactivating Salmonella Typhimurium and E. coli O157:H7 on coriander. Their study also used 4 UV-C doses of $8 \sim 432 \mathrm{~mJ} / \mathrm{cm}^{2}$ along with SAEW washing. The reduction level of pathogens was 1.50 2.42 $\log$ CFU/g, similar to our results with UV-C LED irradiation $(275 \mathrm{~nm})$ at a dose of $4.14 \mathrm{~mJ} / \mathrm{cm}^{2}$.

Green et al. [41] have compared effects for inactivating E. coli O157:H7 surrogate using a low-pressure mercury (LPM) lamp $(253.7 \mathrm{~nm})$ and UV-C LED $(275 \mathrm{~nm})$ at UV-C dose $0 \sim 20 \mathrm{~mJ} / \mathrm{cm}^{2}$. UV-C LED irradiation for the same period of time resulted in a larger log reduction $(\sim 5 \log$ CFU/g) than the LPM lamp, since a warm-up time was not required for UV-C LED irradiation compared to the LPM lamp. Reduction levels of S. aureus on lettuce and strawberry were also observed to be 1.21 and $0.5 \log \mathrm{CFU} / \mathrm{g}$, respectively, after applying UV-C LPM lamp irradiation $(254 \mathrm{~nm})$ for $45 \mathrm{~min}\left(540 \mathrm{~mJ} / \mathrm{cm}^{2}\right)$ [42]. These results indicate that UV-C LED could be efficiently used with a shorter time and a less consumption of energy than UV-C LPM lamp.

3.1.4. Effect of the Kind of Pathogen and Vegetables on Microbial Reduction with SAEW, US, and UV-C LED

In the present study, a more effective reduction was observed for SEA (0.50 2.17 log $\mathrm{CFU} / \mathrm{g})$ than for pathogenic E. coli (0.41 1.59 log CFU/g) in all vegetables except cabbage (Table 3). Generally, Gram-positive bacteria are recognized as more resistant than Gramnegative bacteria, since they have thicker cell walls that can protect against physical and chemical treatments [34,43]. Pathogenic E. coli $(0.30 \sim 1.27 \log$ CFU/g) showed greater reduction than SEA (0.34 0.97 $\log \mathrm{CFU} / \mathrm{g})$ in cabbage of this study. No significant difference in inactivation level between Gram-positive and Gram-negative bacteria after treatment with ultrasound has been reported [44]. On the other hand, Crook et al. [45] have reported that $S$. aureus is the most sensitive bacterium among seven pathogens (L. monocytogenes, E. coli, Serratia marcescens, Salmonella Senftenberg, Yersinia enterocolitica, Aeromonas hydrophila, and $S$. aureus) to UV-C irradiation.

Regarding the kind of vegetable, all treatments were more effective for pathogens in carrot and celery than in paprika and cabbage. When combined treatment of US + SAEW + UV-C LED was applied, the highest reduction levels for pathogenic E. coli and SEA were measured to be 1.48 and $2.17 \log \mathrm{CFU} / \mathrm{g}$, respectively, in carrot, and 1.59 and $2.02 \log$ $\mathrm{CFU} / \mathrm{g}$, respectively, in celery (Table 3, Figure 2). A significantly greater reduction with SAEW + US was observed for pathogenic E. coli and SEA in carrot, while a more effective UV-C LED treatment was observed for both pathogens in celery $(p<0.05)$. Additional UV-C LED irradiation enhanced decontamination effects for carrot and celery. However, these reinforced effects were not significantly different between carrot and celery $(p>0.05)$. Surface characteristic of fresh produce was an important factor affecting inactivation effects of physicochemical treatments such as SAEW, US, and UV-C LED in most studies. Inactivation rates were higher for less hydrophobic fruits with smoother surfaces (apple, pears, and cherry tomato) than for those with rougher surfaces (cantaloupe, strawberry, and raspberry) $[20,46]$. 


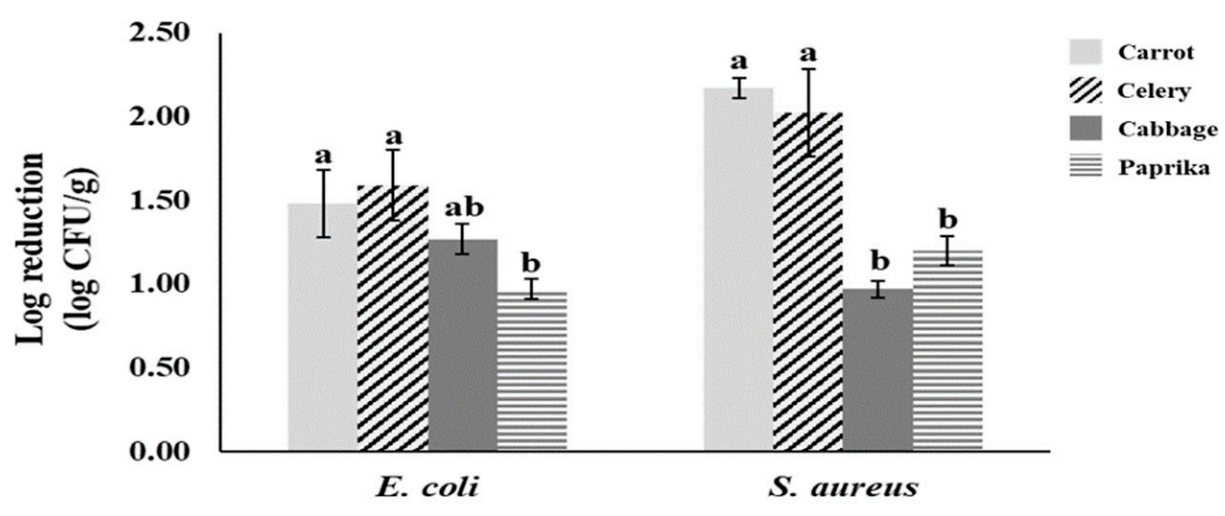

Figure 2. Comparison for reduction effect of combined treatment with SAEW + US + UV-C LED on pathogenic E coli (cocktail of EPEC, ETEC, and E. coli O157:H7) and S. aureus (SEA) in various vegetables. The data were obtained from a non-selective media. ${ }^{a, b}$ Values within each treatment represent different by Duncan's multiple tests at $p<0.05$.

The surface of celery itself is smoother than that of carrot. However, due to a lot of regular groove shapes, a more significant reduction effect of SAEW + US was observed for carrots than for celeries during this study's washing step. However, a better disinfection effect was observed for celeries than for carrots with UV-C LED irradiation. In the present study, a relatively lower microbial reduction effect was observed for paprika and cabbage.

Moreover, a similar reduction effect in pathogenic E. coli and SEA was noticed in cabbage and paprika.

Since the effect of disinfection treatment was affected by various factors such as surface properties of vegetables, adherence characteristics of pathogen on the surface of different vegetables, additional hurdle technology might be needed during processing and distribution of various kinds of fresh-cut vegetables.

\subsection{Quality Evaluation of Treated Vegetables during Storage at 5 and $15{ }^{\circ} \mathrm{C}$}

3.2.1. Survival of Pathogenic E. coli and S. aureus on Fresh-Cut Vegetables after Combined Treatment

After combined treatment with SAEW + US + UV-C LED, survival characteristics of pathogenic E. coli and enterotoxin A-producing S. aureus (SEA) inoculated on fresh-cut carrot, celery, cabbage, and paprika were investigated after storage at $5{ }^{\circ} \mathrm{C}$ (storage temperature) and $15{ }^{\circ} \mathrm{C}$ (abused temperature) for 7 days. At $5^{\circ} \mathrm{C}$, the combined treatment decreased both pathogens' populations to the lowest level $(1.5 \operatorname{logs} \mathrm{CFU} / \mathrm{g})$ in all vegetables (data not shown). At $15^{\circ} \mathrm{C}$, the growth of pathogenic E. coli was inhibited in only carrot and celery treated with SAEW + US or SAEW + US + UV-C LED during storage (Figure 3A). The population of E. coli treated with SAEW + US + UV-C LED was increased up to $7.7 \mathrm{log}$ CFU/g in cabbage, which was lower than the population in the non-treated sample $(8.8 \log \mathrm{CFU} / \mathrm{g})$. The growth of $E$. coli was not also inhibited in paprika treated with SAEW + US or SAEW + US + UV-C LED.

On the other hand, the combined treatment decreased SEA populations to the lowest level (1.5 log CFU/g) in carrots and celeries after storage at $15{ }^{\circ} \mathrm{C}$ for 7 days (Figure 3B). Similar results were found after storage at $5{ }^{\circ} \mathrm{C}$. The populations of SEA decreased in cabbage treated with SAEW + US or SAEW + US + UV-C LED, while SEA population was not changed in the non-treated cabbage during 7 days of storage at $15^{\circ} \mathrm{C}$. On the other hand, the populations of SEA were not changed in paprika during 7 days of storage at $15^{\circ} \mathrm{C}$, regardless of treatment, indicating that SEA in paprika was the least affected by SAEW + US or SAEW + US + UV-C LED. Overall, the growth control was more effective for SEA in all vegetables than for pathogenic $E$. coli based on reduction effects of treatments (Table 3, Figure 3). A more rapid reduction in SEA in carrots and celeries than in cabbage and paprika during storage at $15^{\circ} \mathrm{C}$ was noticed. 
(A) Pathogenic E. coli

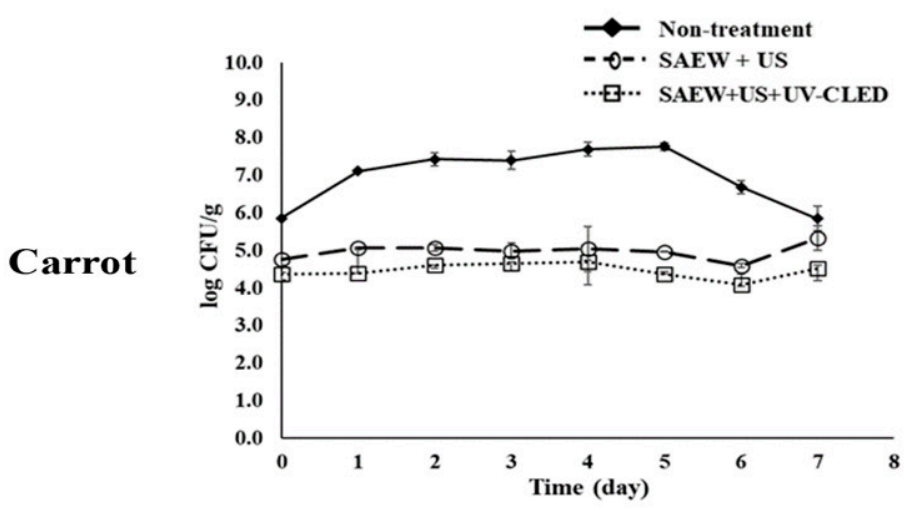

Celery

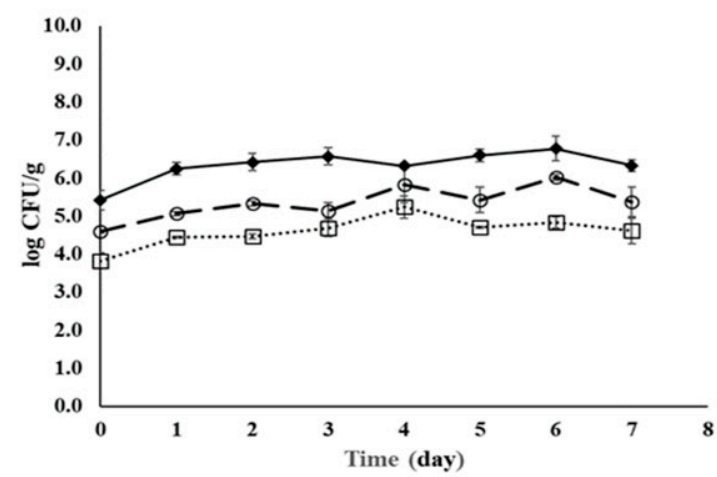

Cabbage

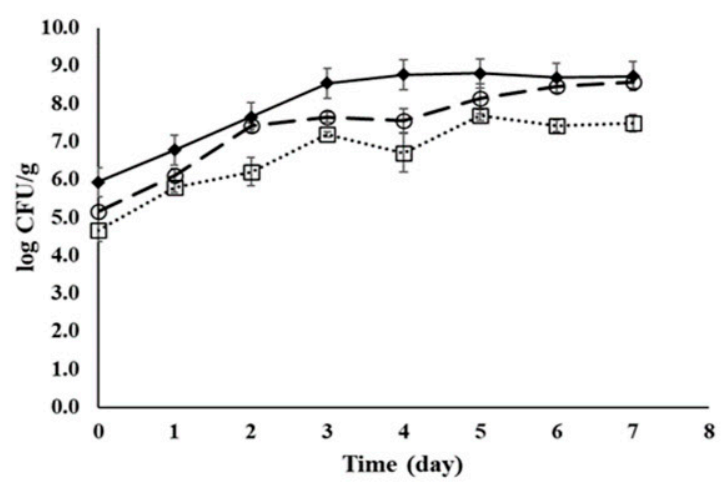

Paprika

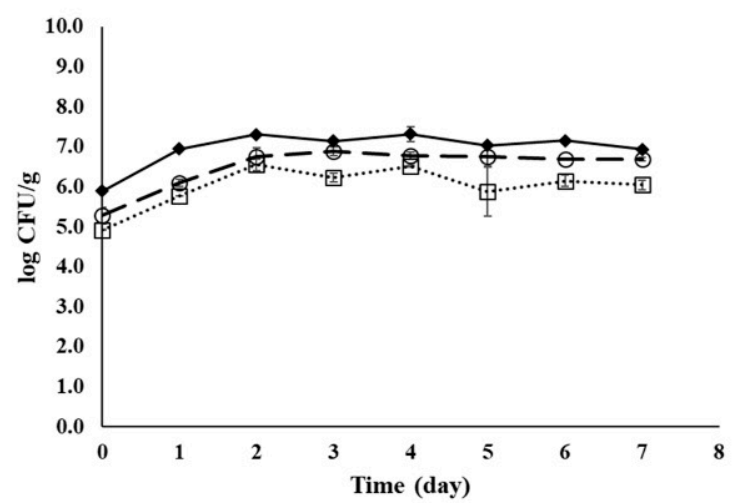

(B) S. aureus (SEA)
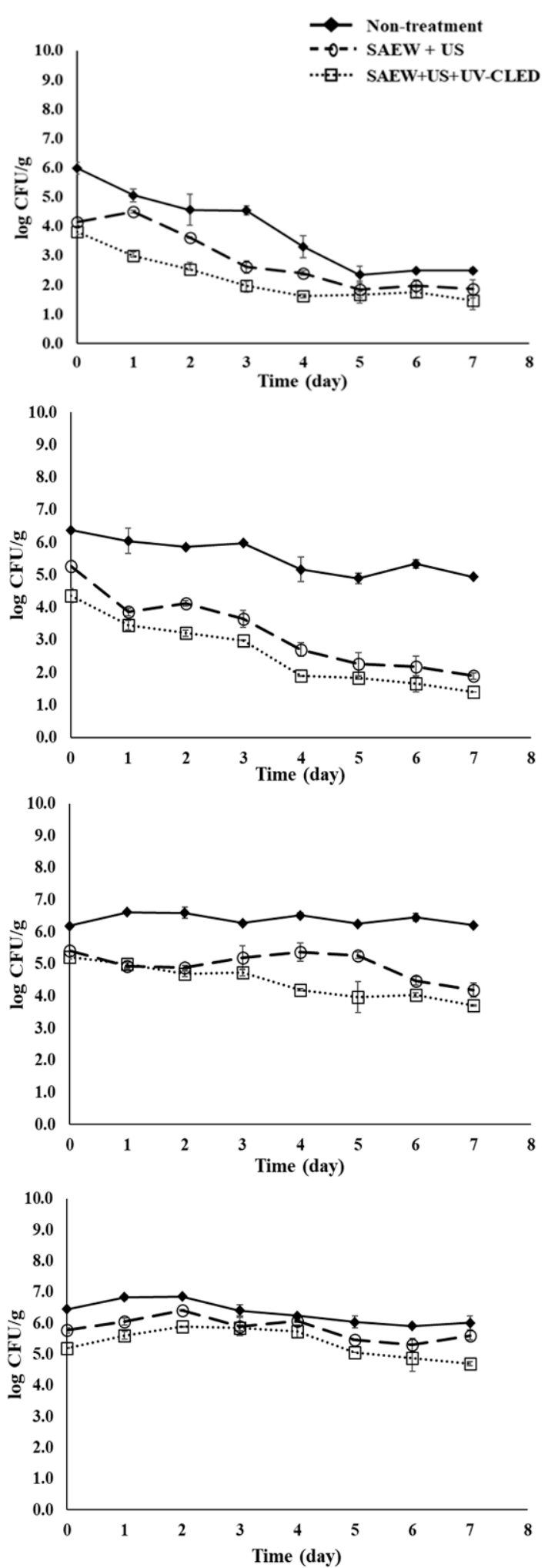

Figure 3. Effect of combined treatment on the survival of (A) pathogenic E. coli (cocktail of EPEC, ETEC, and E. coli O157:H7) and (B) S. aureus (SEA) in fresh-cut carrot, celery, cabbage and paprika stored for 7 days at $15{ }^{\circ} \mathrm{C}$. Non-treatment, no extra wash with a sanitizer; SAEW, slightly acidic electrolyzed water; US, ultrasounds; UV-C LED, ultraviolet-C light-emitting diodes $(275 \mathrm{~nm})$; the data were obtained from a selective media. 
Previous studies have reported the survival of foodborne pathogens in vegetables after different treatments $[19,32]$. Total bacterium counts on lettuce and button mushroom applied combined treatment with SAEW and US are lower than those without treatments after 6-8 days of storage at 4 and $10^{\circ} \mathrm{C}$ [19,32]. Jiang et al. [28] have also studied the reduction effect of combined treatment with SAEW and UV-LED on Salmonella Typhimurium and E. coli O157:H7 in coriander after 6 days of storage at $4{ }^{\circ} \mathrm{C}$. Among tested samples, SAEW + UV-LED-treated samples showed the lowest levels of Salmonella Typhimurium and E. coli O157:H7. Combined treatment of SAEW, US, and UV-C LED show synergistic effects due to the impact of chlorine compounds, cavitation, and ultraviolet-C, causing structural damage of cell membrane efficiently $[17,26,47,48]$. A synergistic effect was also observed for pathogenic bacteria on vegetables treated with SAEW + US + UV-C LED in the present study, indicating that such combined technology might be effective in extending the shelf life of fresh-cut vegetables. The most effective method of elimination Shiga toxin (verotoxin)-producing E coli (STEC) from foods is to introduce a bactericidal treatment, such as heating or gamma irradiation $[49,50]$. The present results show that UV-C LED treatment with washing can replace the gamma irradiation in the fresh-cut vegetable industry. However, the retail market's storage temperature must not be abused, since the growth of pathogenic E. coli was not prevented by such treatment at $15^{\circ} \mathrm{C}$.

Overall, the growth of pathogens in carrot and celery was controlled better than in cabbage and paprika at 5 and $15^{\circ} \mathrm{C}$. Antimicrobial activities of water-soluble polysaccharides in carrot and sedanolide (aroma component) in celery might explain such results [51,52]. Consequently, it can be concluded that combined treatment may extend the shelf life of fresh-cut vegetables, although the microbial reduction effect may vary depending on the characteristics of vegetables.

\subsubsection{Effects of Combined Treatments on Quality Parameters of Fresh-Cut Vegetables}

To evaluate the effects of various treatments on quality parameters of fresh-cut carrot, celery, cabbage, and paprika, moisture loss (Figure 4), appearance (Figure 5), and instrumental color (Table 4) were measured during storage at 5 and $15{ }^{\circ} \mathrm{C}$ for 7 days. Figure 4 shows changes in moisture in samples treated with SAEW + US or SAEW + US + UV-C LED and stored for 7 days at $5{ }^{\circ} \mathrm{C}$ compared to non-treated samples.

The lowest moisture loss with SAEW + US + UV-C LED treatment was noticed for celery $(1.4 \%)$ and cabbage $(2.5 \%)$ after storage for 7 days. Such moisture loss was lower than that with SAEW + US or non-treated samples (3.7 9.0\%). However, changes in moisture in carrot (Figure $4 \mathrm{a}$ ) and paprika (Figure $4 \mathrm{~d}$ ) were observed to have similar levels at all conditions. A similar tendency of moisture loss was noticed at $15{ }^{\circ} \mathrm{C}$ (data not shown). Generally, a loss of moisture greater than $5 \%$ would cause a reduction in the retail value of vegetables and fruits [53]. The threshold level of moisture loss is $10 \%$ for ending the shelf life of fresh produce [54]. Regardless of treatment, less than 5\% of moisture loss was observed for carrot and paprika. Less than $5 \%$ of moisture loss was also observed for celery and cabbage treated with SAEW + US or SAEW + US + UV-C LED in the present study. Other studies have also reported that moisture losses in tomatoes treated with the US and UV-C [55] and yellow bell pepper treated with UV-C irradiation [56] are lower than those in non-treated samples. Treatments with the US and various sanitization agents did not affect purple cabbage moisture during storage [57]. It is also reported that the combination of SAEW and ultrasound had no significant effect on the contents of total soluble solids, vitamin C, or total titratable acidity in both strawberries and cherry tomatoes [20]. Total phenol and ascorbic acid contents of UV-C-treated yellow bell pepper remained constant during refrigerated storage [56]. These results showed that UV-C is an effective non-chemical treatment to maintain the qualities of fruits and vegetables. 


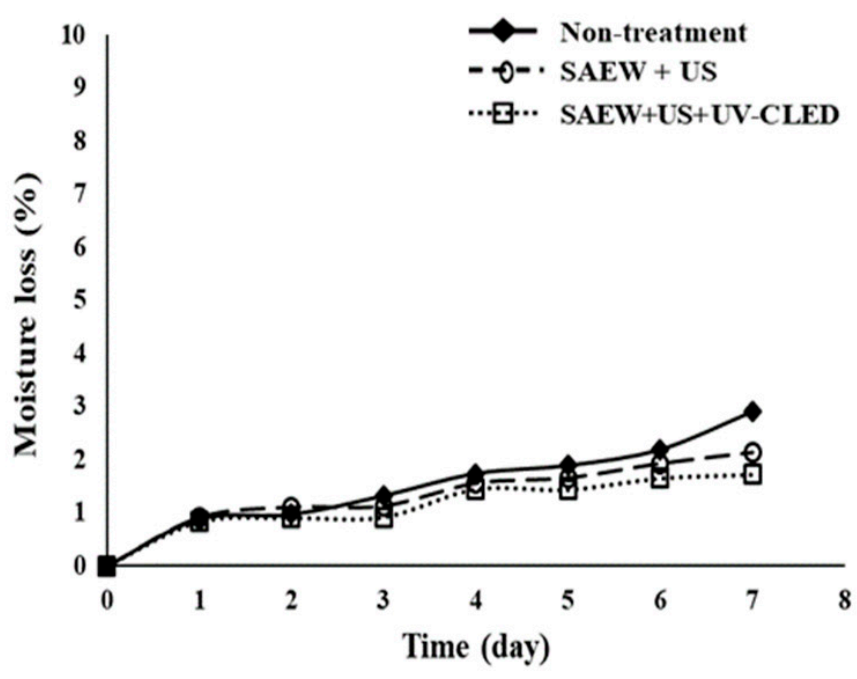

(a)

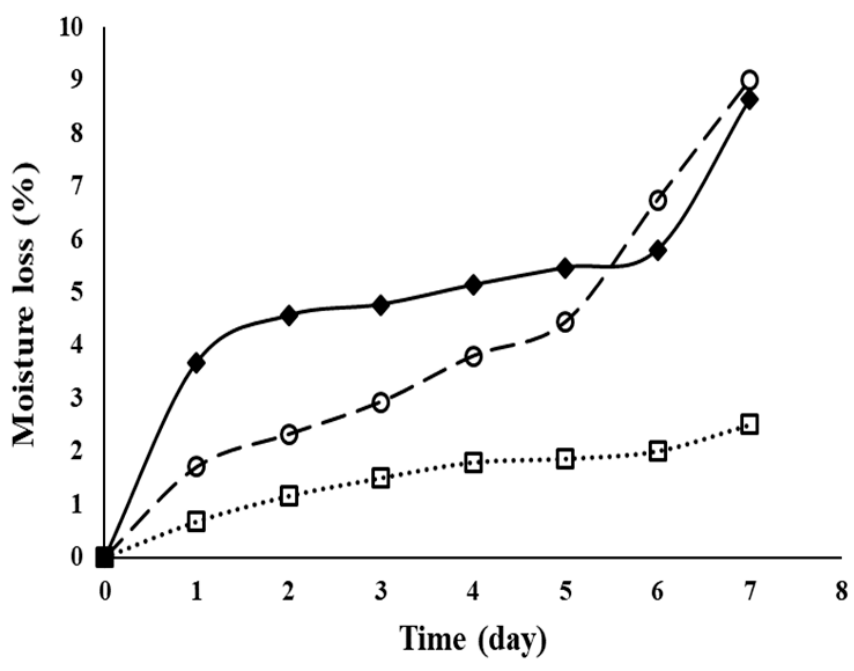

(c)

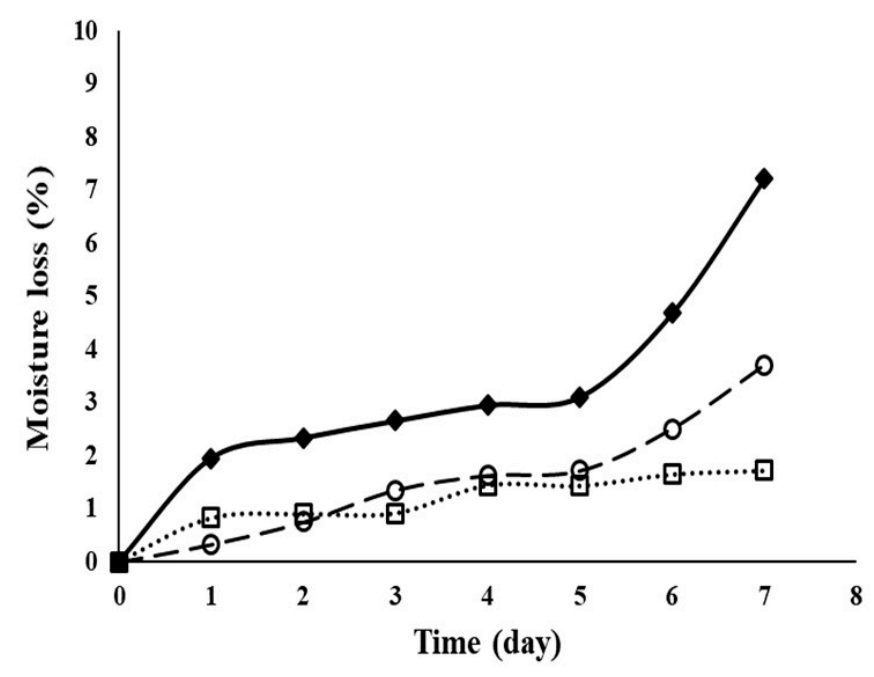

(b)

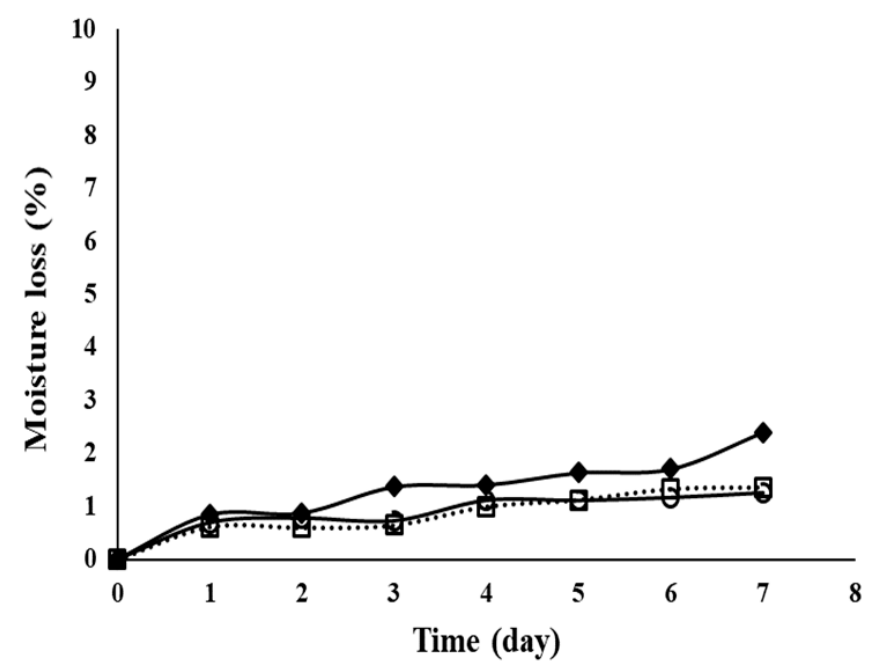

(d)

Figure 4. Effect of combined treatment on the moisture loss in various fresh-cut vegetables stored for 7 days at $5{ }^{\circ} \mathrm{C}$. (a) Carrot, (b) celery, (c) cabbage, (d) paprika; non-treatment, no extra wash with a sanitizer; SAEW, slightly acidic electrolyzed water; US, ultrasounds; UV-C LED, ultraviolet-C light-emitting diodes (275 nm); non-treatment, no extra wash with a sanitizer. 

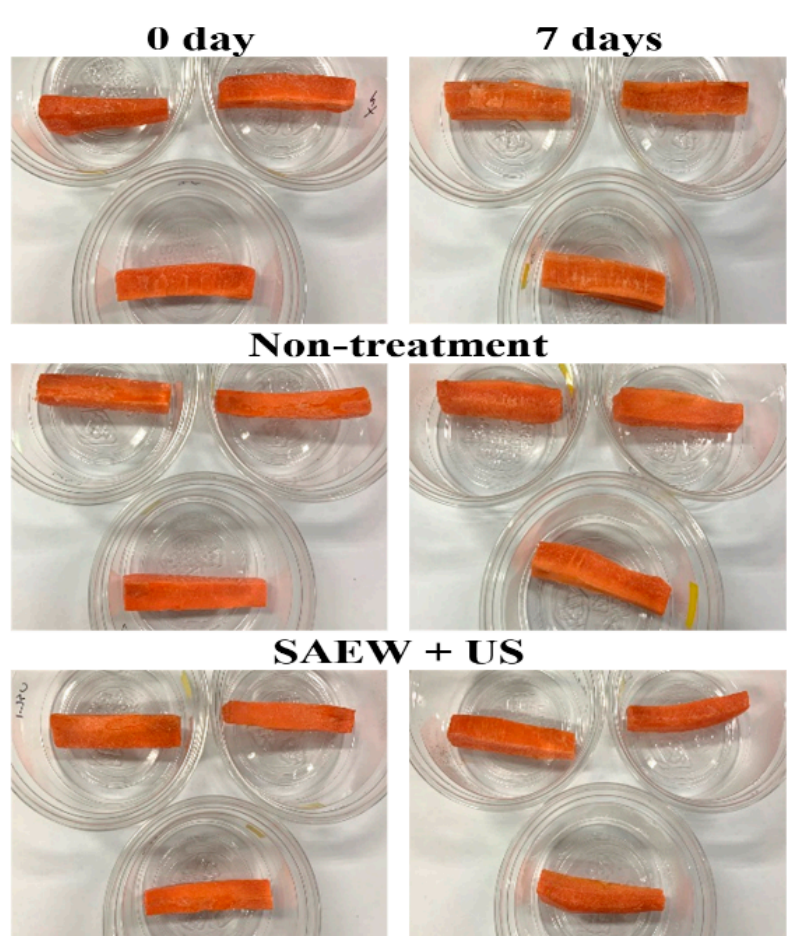

SAEW+US+UV-C LED

(a)
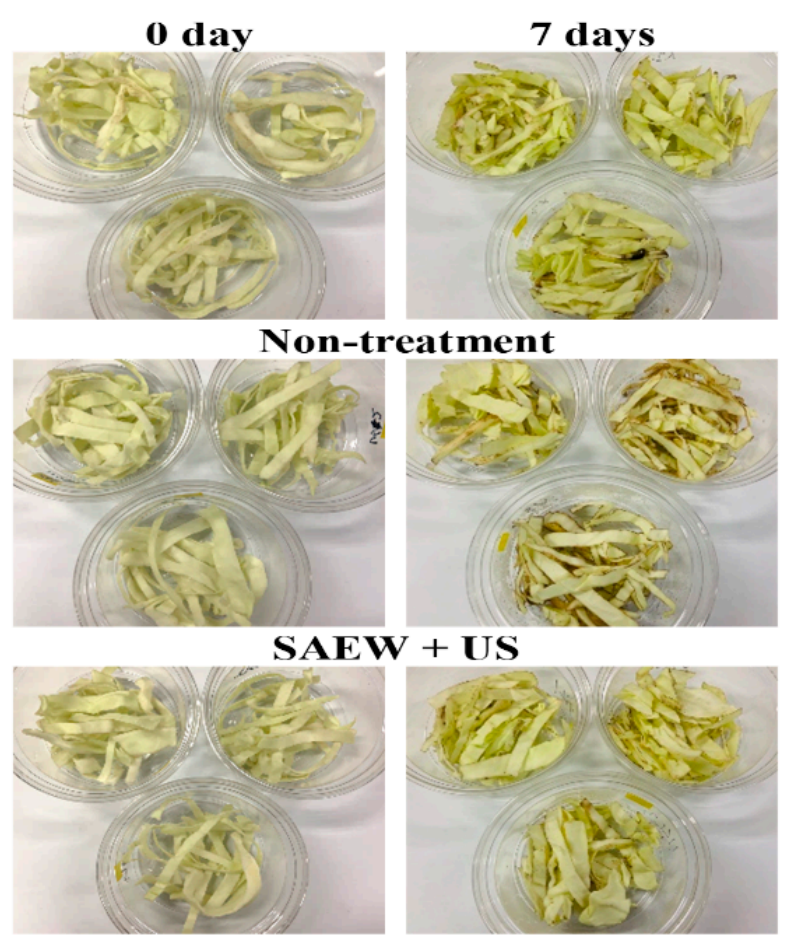

SAEW+US+UV-C LED

(c)
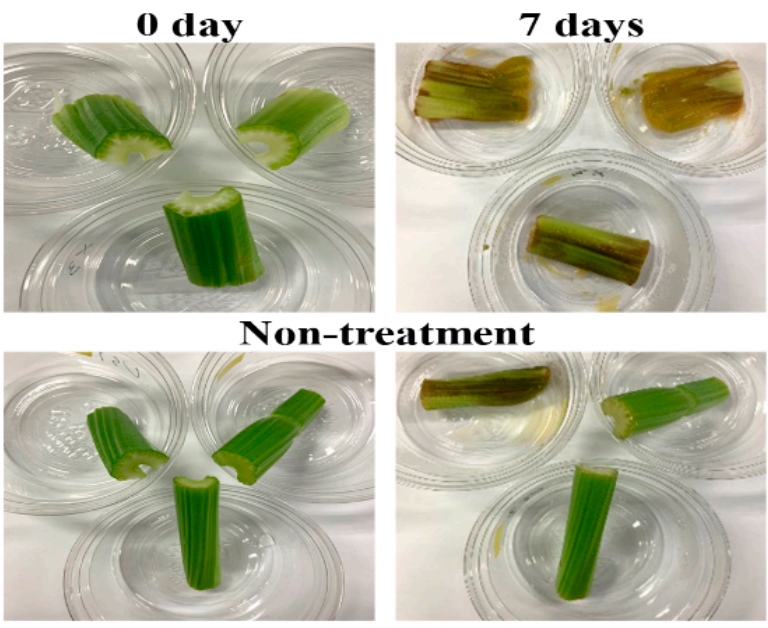

SAEW + US

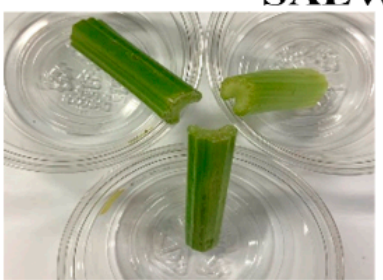

SAEW+US+UV-C LED

(b)
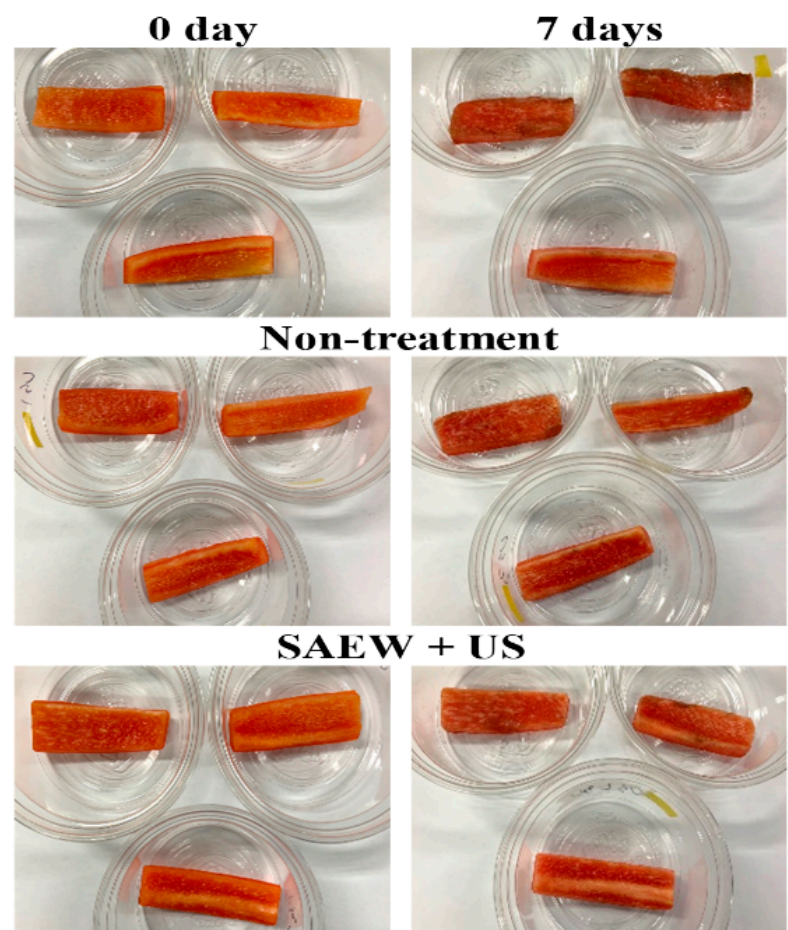

SAEW+US+UV-C LED

(d)

Figure 5. Effect of combined treatments on visible qualities in various fresh-cut vegetables after storage for 7 days at $15{ }^{\circ} \mathrm{C}$. (a) Carrot, (b) celery, (c) cabbage, (d) paprika; non-treatment, no extra wash with a sanitizer; SAEW, slightly acidic electrolyzed water; US, ultrasounds; UV-C LED, ultraviolet-C light-emitting diodes (275 nm). 
Table 4. Effect of combined treatments on hunter color values in fresh-cut vegetables after storage for 7 days at $15^{\circ} \mathrm{C}$.

\begin{tabular}{|c|c|c|c|c|c|c|c|}
\hline & \multirow{2}{*}{ Samples } & \multicolumn{2}{|c|}{$L^{*}$} & \multicolumn{2}{|c|}{$a^{*}$} & \multicolumn{2}{|c|}{$b^{*}$} \\
\hline & & 0 Day & 7 Days & 0 Day & 7 Days & 0 Day & 7 Days \\
\hline \multirow[t]{2}{*}{ Carrot } & \multirow{2}{*}{$\begin{array}{c}\text { Non-treatment } \\
\text { SAEW + US } \\
\text { SAEW + US + UV-C } \\
\text { LED }\end{array}$} & $\begin{array}{c}55.46 \pm 1.30^{1} \\
50.24 \pm 0.59\end{array}$ & $\begin{array}{l}* 57.02 \pm 0.53 \\
* 53.96 \pm 1.90\end{array}$ & $\begin{array}{l}32.79 \pm 0.26 \\
31.57 \pm 1.15\end{array}$ & $\begin{array}{l}* 25.91 \pm 1.06 \\
* 27.49 \pm 0.89\end{array}$ & $\begin{array}{l}29.73 \pm 1.59 \\
29.11 \pm 0.47\end{array}$ & $\begin{array}{l}* 24.44 \pm 1.37 \\
* 26.04 \pm 2.30\end{array}$ \\
\hline & & $50.66 \pm 0.93$ & $51.94 \pm 1.79$ & $30.38 \pm 0.14$ & $30.39 \pm 0.33$ & $29.55 \pm 0.41$ & $* 27.29 \pm 0.17$ \\
\hline \multirow[t]{2}{*}{ Celery } & \multirow{2}{*}{$\begin{array}{c}\text { Non-treatment } \\
\text { SAEW + US } \\
\text { SAEW + US + UV-C } \\
\text { LED }\end{array}$} & $\begin{array}{l}50.68 \pm 1.12 \\
44.78 \pm 1.20\end{array}$ & $\begin{array}{c}* 36.48 \pm 0.16 \\
42.54 \pm 2.18\end{array}$ & $\begin{array}{l}-13.93 \pm 0.15 \\
-13.13 \pm 0.32\end{array}$ & $\begin{array}{l}*-3.20 \pm 1.13 \\
*-7.00 \pm 0.25\end{array}$ & $\begin{array}{l}21.58 \pm 1.16 \\
18.75 \pm 0.42\end{array}$ & $\begin{array}{c}* 15.22 \pm 0.08 \\
18.16 \pm 1.48\end{array}$ \\
\hline & & $48.43 \pm 2.84$ & $50.44 \pm 2.99$ & $-14.01 \pm 0.26$ & $-12.96 \pm 1.77$ & $20.67 \pm 1.13$ & $21.30 \pm 1.42$ \\
\hline \multirow[t]{2}{*}{ Cabbage } & \multirow{2}{*}{$\begin{array}{c}\text { Non-treatment } \\
\text { SAEW + US } \\
\text { SAEW + US + UV-C } \\
\text { LED }\end{array}$} & $\begin{array}{l}80.88 \pm 2.45 \\
79.56 \pm 1.94\end{array}$ & $\begin{array}{l}* 64.03 \pm 0.47 \\
* 75.07 \pm 0.28\end{array}$ & $\begin{array}{l}-3.30 \pm 1.20 \\
-3.72 \pm 0.25\end{array}$ & $\begin{array}{l}*-6.60 \pm 1.86 \\
*-5.69 \pm 0.51\end{array}$ & $\begin{array}{c}9.85 \pm 0.68 \\
11.08 \pm 0.04\end{array}$ & $\begin{array}{l}* 17.81 \pm 0.90 \\
* 16.97 \pm 0.50\end{array}$ \\
\hline & & $79.12 \pm 1.72$ & $77.38 \pm 2.23$ & $-3.21 \pm 0.46$ & $-3.55 \pm 0.30$ & $10.24 \pm 2.41$ & $* 14.97 \pm 0.53$ \\
\hline \multirow[t]{2}{*}{ Paprika } & \multirow{2}{*}{$\begin{array}{c}\text { Non-treatment } \\
\text { SAEW + US } \\
\text { SAEW + US + UV-C } \\
\text { LED }\end{array}$} & $\begin{array}{l}31.55 \pm 0.71 \\
32.81 \pm 0.08\end{array}$ & $\begin{array}{l}* 27.37 \pm 1.54 \\
* 28.21 \pm 1.03\end{array}$ & $\begin{array}{l}14.48 \pm 0.21 \\
14.82 \pm 0.42\end{array}$ & $\begin{array}{c}* 11.97 \pm 0.16 \\
14.40 \pm 0.59\end{array}$ & $\begin{array}{l}12.00 \pm 0.65 \\
11.64 \pm 0.48\end{array}$ & $\begin{array}{l}* 10.53 \pm 0.50 \\
* 10.67 \pm 0.64\end{array}$ \\
\hline & & $31.10 \pm 1.41$ & $30.29 \pm 0.88$ & $15.18 \pm 0.20$ & $15.52 \pm 0.42$ & $10.76 \pm 0.09$ & $10.23 \pm 0.46$ \\
\hline
\end{tabular}

Non-treatment, no extra wash with a sanitizer, SAEW, slightly acidic electrolyzed water; US, ultrasounds; UV-C LED, ultraviolet-C light-emitting diodes $(275 \mathrm{~nm}) .{ }^{1}$ The average value $(n=6) \pm$ standard deviation of two experiments. During each experiment at least three samples of each vegetable were taken. Each value was measured for at least five points in each vegetable.* Significant difference between stored vegetable samples for 0 day and 7 days was observed at each condition $(p<0.05)$.

Appearance changes in fresh-cut vegetables stored at $15{ }^{\circ} \mathrm{C}$ are shown in Figure 5. After 7 days of storage, conspicuous appearance changes in non-treated celery, cabbage, and paprika were identified at an abused temperature of $15{ }^{\circ} \mathrm{C}$ compared to samples treated with SAEW + US + UV-C LED. However, appearance changes were not noticed for non-treated samples and samples treated with a combination of methods after storage at $5{ }^{\circ} \mathrm{C}$ for 7 days (data not shown). Overall, significant changes in values of $L^{*}, a^{*}$, and $b^{*}$ were not observed for samples treated with SAEW + US + UV-C LED after 7 days of storage at $15^{\circ} \mathrm{C}$ compared to SAEW + US or non-treated samples $(p>0.05)$ (Table 4$)$. Based on visual inspection for sliced button mushrooms, application of SAEW and US treatments delayed browning after 8 days of storage at $5{ }^{\circ} \mathrm{C}$ [19]. Other previous works [56-58] have also reported that $L^{*}, a^{*}$, and $b^{*}$ values were not affected for purple cabbage, tomato, and yellow bell pepper treated with the US, chemical sanitizer, and UV-C technologies during storage at $8 \sim 12{ }^{\circ} \mathrm{C}$. The present study also proved that combined treatment of SAEW + US + UV-C LED prevented the color change in fresh-cut vegetables and could be applied to maintain the quality and safety of fresh-cut vegetables.

\section{Conclusions}

In the present study, combined treatment with 30 ppm SAEW + US + UV-C LED before packaging was more effective in reducing microbial contamination than every single treatment. Combined treatment with SAEW, US, and UV-C LED further reduced populations of pathogenic E. coli and enterotoxin A-producing S. aureus (SEA) in fresh-cut vegetables. Combined treatments (SAEW + US or SAEW + US + UV-C LED) reduced populations of pathogenic $E$. coli and SEA to the lowest levels in all vegetables after storage at $5{ }^{\circ} \mathrm{C}$ for 7 days. The growth of pathogenic E. coli and SEA was more effectively inhibited in carrot and celery than in cabbage and paprika treated with SAEW + US + UV-C LED during storage at an abused temperature of $15^{\circ} \mathrm{C}$. Overall, the growth control by combined treatment was more effective for SEA than for pathogenic E. coli. It was also noticed that combined treatment with SAEW + US + UV-C LED prevented moisture loss, color, and appearance change during storage at 5 and $15^{\circ} \mathrm{C}$. These results indicate that combined treatment of SAEW, US, and UV-C LED can be applied as a useful technology to extend the shelf life of fresh-cut vegetables. However, its effect may vary depending on the characteristics of vegetables. Especially, UV-C LED can be suggested as a new hurdle technology in the fresh-cut vegetable industry. 
Author Contributions: Investigation, J.Y.L. and S.Y.Y.; methodology, J.Y.L. and K.S.Y.; project administration, K.S.Y.; writing—original draft, J.Y.L.; writing—review and editing, K.S.Y. All authors have read and agreed to the published version of the manuscript.

Funding: This research was funded by the Ministry of Food and Drug Safety, grant number 20162MFDS012.

Institutional Review Board Statement: Not applicable.

Informed Consent Statement: Not applicable.

Data Availability Statement: We did not report any additional data for this study.

Acknowledgments: This research was funded by the Ministry of Food and Drug Safety, grant number 20162MFDS012. The authors appreciated Ji Soo Lee for her support of the experiment.

Conflicts of Interest: The authors declare no conflict of interest.

\section{References}

1. Korea Agro-Fisheries \& Food Trade Corporation (KAFFTC). Processed Food Subdivision Market Status: Ready-to-Eat Fresh-Cut Produce. Available online: https: / / atfis.or.kr/article/M001050000/view.do?articleId=2398\&page=\&searchKey=\&searchString= \&searchCategory $=$ (accessed on 9 December 2020).

2. Yi, N.Y.; Choi, J.H. A Study of the consumer perception of meal kit using big data analysis. Food Serv. Ind. J. 2019, 15, $211-222$.

3. Ministry of Food and Drug Safety (MFDS). Korean Food Code. Available online: https://www.foodsafetykorea.go.kr/foodcode/ 01_03.jsp?idx=63 (accessed on 13 June 2020).

4. Korea Rural Economic Institute (KREI). A Study on the Status and Policy Issues the Home Meal Replacement (HMR) Industry in Korea. Available online: http:/ / www.krei.re.kr/eng/research.do?key=355\&pageType=010101 (accessed on 9 December 2020).

5. Oh, T.Y.; Baek, S.Y.; Choi, J.H.; Jeong, M.C.; Koo, O.K.; Kim, S.M.; Kim, H.J. Analysis of foodborne pathogens in brassica campestris var. Narinosa microgreen from harvesting and processing steps. J. Appl. Biol. Chem. 2016, 59, 63-68. [CrossRef]

6. Ministry of Food and Drug Safety (MFDS). Statistics for Foodborne Illness Outbreaks. Available online: https://www. foodsafetykorea.go.kr/portal/healthyfoodlife/foodPoisoningStat.do?menu_no=3724\&menu_grp=MENU_NEW02 (accessed on 7 May 2020).

7. Centers for Disease Control and Prevention (CDC). Multistate Outbreak of E. coli O157:H7 Infections Linked to Romaine Lettuce. Available online: https:/ / www.cdc.gov/ecoli/2018/o157h7-04-18/ (accessed on 15 June 2020).

8. Centers for Disease Control and Prevention (CDC). National Outbreak Reporting System (NORS). Available online: https: //www.cdc.gov/norsdashboard/ (accessed on 15 June 2020).

9. European Food Safety Authority (EFSA). Shiga toxin-producing E. coli (STEC) O104:H4 2011 Outbreaks in Europe: Taking Stock. EFSA J. 2011, 9, 2390. [CrossRef]

10. King, L.A.; Nogareda, F.; Weill, F.X.; Mariani-Kurkdjian, P.; Loukiadis, E.; Gault, G.; Jourdan-DaSilva, N.; Bingen, E.; Macé, M.; Thevenot, D.; et al. Outbreak of shiga toxin-producing Escherichia coli O104:H4 associated with organic fenugreek sprouts, France, June 2011. Clin. Infect. Dis. 2012, 54, 1588-1594. [CrossRef] [PubMed]

11. Castro-Rosas, J.; Cerna-Cortés, J.F.; Méndez-Reyes, E.; Lopez-Hernandez, D.; Gómez-Aldapa, C.A.; Estrada-Garcia, T. Presence of faecal coliforms, Escherichia coli and diarrheagenic E. coli pathotypes in ready-to-eat salads, from an area where crops are irrigated with untreated sewage water. Int. J. Food Microbiol. 2012, 156, 176-180. [CrossRef]

12. Faour-Klingbeil, D.; Murtada, M.; Kuri, V.; Todd, E.C.D. Understanding the routes of contamination of ready-to-eat vegetables in the Middle East. Food Control 2016, 62, 125-133. [CrossRef]

13. Shah, M.S.; Eppinger, M.; Ahmed, S.; Shah, A.A.; Hameed, A.; Hasan, F. Multidrug-resistant diarrheagenic E. coli pathotypes are associated with ready-to-eat salad and vegetables in Pakistan. J. Korean Soc. Appl. Biol. Chem. 2015, 58, 267-273. [CrossRef]

14. Balali, G.I.; Yar, D.D.; Afua Dela, V.G.; Adjei-Kusi, P. Microbial contamination, an increasing threat to the consumption of fresh fruits and vegetables in today's world. Int. J. Microbiol. 2020, 1, 1-13. [CrossRef]

15. Koide, S.; Shitanda, D.; Note, M.; Cao, W. Effects of mildly heated, slightly acidic electrolyzed water on the disinfection and physicochemical properties of sliced carrot. Food Control 2011, 22, 452-456. [CrossRef]

16. Lee, H.H.; Hong, S.I.; Kim, D. Microbial reduction efficacy of various disinfection treatments on fresh-cut cabbage. Food Sci. Nutr. 2014, 2, 585-590. [CrossRef] [PubMed]

17. Hulsmans, A.; Joris, K.; Lambert, N.; Rediers, H.; Declerck, P.; Delaedt, Y.; Delaedt, Y.; Oilevier, F.; Liers, S. Evaluation of process parameters of ultrasonic treatment of bacterial suspensions in a pilot scale water disinfection system. Ultrasonics Sonochem. 2010, 17, 1004-1009. [CrossRef]

18. Pinela, J.; Ferreira, I.C.F.R. Nonthermal physical technologies to decontaminate and extend the shelf-life of fruits and vegetables: Trends aiming at quality and safety. Crit. Rev. Food Sci. Nutr. 2017, 57, 2095-2111. [CrossRef]

19. Wu, S.; Nie, Y.; Zhao, J.; Fan, B.; Huang, X.; Li, X.; Sheng, J.; Meng, D.; Ding, Y.; Tang, X. The synergistic effects of low-concentration acidic electrolyzed water and ultrasound on the storage quality of fresh-sliced button mushrooms. Food Bioprocess Technol. 2018, 11, 314-323. [CrossRef] 
20. Ding, T.; Ge, Z.; Shi, J.; Xu, Y.T.; Jones, C.L.; Liu, D.H. Impact of slightly acidic electrolyzed water (SAEW) and ultrasound on microbial loads and quality of fresh fruits. LWT Food Sci. Technol. 2015, 60, 1195-1199. [CrossRef]

21. Luo, K.; Oh, D.-H. Inactivation kinetics of Listeria monocytogenes and Salmonella enterica serovar Typhimurium on fresh-cut bell pepper treated with slightly acidic electrolyzed water combined with ultrasound and mild heat. Food Microbiol. 2016, 53, 165-171. [CrossRef] [PubMed]

22. Guerrero-Beltrán, J.A.; Barbosa-Cánovas, G.V. Review: Advantages and limitations on processing foods by UV light. Food Sci. Technol. Int. 2004, 10, 137-147. [CrossRef]

23. Koutchma, T. Advances in ultraviolet light technology for non-thermal processing of liquid foods. Food Bioprocess Technol. 2009, 2, 138-155. [CrossRef]

24. Koutchma, T.; Orlowska, M. Ultraviolet light for processing fruits and fruit products. In Advances in Fruit Processing Technologies, 1st ed.; Rodrigues, S., Fernandes, F.A.N., Eds.; CRC Press: Boca Raton, FL, USA, 2012; pp. 1-36.

25. Aihara, M.; Lian, X.; Shimohata, T.; Uebanso, T.; Mawatari, K.; Harada, Y.; Akutagawa, M.; Kinouchi, Y.; Takahashi, A. Vegetable surface sterilization system using uva light-emitting diodes. J. Med. Investig. 2014, 61, 285-290. [CrossRef]

26. Akgün, M.P.; Ünlütürk, S. Effects of ultraviolet light emitting diodes (LEDs) on microbial and enzyme inactivation of apple juice. Int. J. Food Microbiol. 2017, 260, 65-74. [CrossRef] [PubMed]

27. de Souza, V.R.; Popović, V.; Warriner, K.; Koutchma, T. A comparative study on the inactivation of Penicillium expansum spores on apple using light emitting diodes at $277 \mathrm{~nm}$ and a low-pressure mercury lamp at $253.7 \mathrm{~nm}$. Food Control 2020, 110, 107039. [CrossRef]

28. Jiang, Y.; Ai, C.; Liao, X.; Liu, D.; Ding, T. Effect of slightly acidic electrolyzed water (SAEW) and ultraviolet light illumination pretreatment on microflora inactivation of coriander. LWT 2020, 132, 109898. [CrossRef]

29. Luo, K.; Kim, S.Y.; Wang, J.; Oh, D.H. A combined hurdle approach of slightly acidic electrolyzed water simultaneous with ultrasound to inactivate Bacillus cereus on potato. LWT Food Sci. Technol. 2016, 73, 615-621. [CrossRef]

30. Kim, S.Y.; Oh, D.H. Predictive modeling of Bacillus cereus on carrot treated with slightly acidic electrolyzed water and Ultrasonication at various storage temperatures. J. Korean Soc. Food Sci. Nutr. 2014, 43, 1296-1303. [CrossRef]

31. Ding, T.; Rahman, S.M.E.; Oh, D.H. Inhibitory effects of low concentration electrolyzed water and other sanitizers against foodborne pathogens on oyster mushroom. Food Control 2011, 22, 318-322. [CrossRef]

32. Forghani, F.; Rahman, S.M.E.; Park, M.S.; Park, J.H.; Park, J.; Song, K.B.; Oh, D.H. Ultrasonication enhanced low concentration electrolyzed water efficacy on bacteria inactivation and shelf life extension on lettuce. Food Sci. Biotechnol. 2013, 22, 131-136. [CrossRef]

33. Rahman, S.M.E.; Wang, J.; Oh, D.H. Synergistic effect of low concentration electrolyzed water and calcium lactate to ensure microbial safety, shelf life and sensory quality of fresh pork. Food Control 2013, 30, 176-183. [CrossRef]

34. Ananta, E.; Voigt, D.; Zenker, M.; Heinz, V.; Knorr, D. Cellular injuries upon exposure of Escherichia coli and Lactobacillus rhamnosus to high-intensity ultrasound. J. Appl. Microbiol. 2005, 99, 271-278. [CrossRef]

35. Ulusoy, B.H.; Colak, H.; Hampikyan, H. The use of ultrasonic waves in food technology. Res. J. Biol. Sci. 2007, 2, 491-497.

36. Shin, J.Y.; Kim, S.J.; Kim, D.K.; Kang, D.H. Fundamental characteristics of deep-UV light-emitting diodes and their application to control foodborne pathogens. Appl. Environ. Microbiol. 2016, 82, 2-10. [CrossRef]

37. Forghani, F.; Oh, D.H. Hurdle enhancement of slightly acidic electrolyzed water antimicrobial efficacy on Chinese cabbage, lettuce, sesame leaf and spinach using ultrasonication and water wash. Food Microbiol. 2013, 36, 40-45. [CrossRef]

38. Hussain, M.S.; Kwon, M.; Park, E.; Seheli, K.; Huque, R.; Oh, D.H. Disinfection of Bacillus cereus biofilms on leafy green vegetables with slightly acidic electrolyzed water, ultrasound and mild heat. LWT 2019, 116, 108582. [CrossRef]

39. Mansur, A.R.; Oh, D.H. Combined effect of thermosonication and slightly acidic electrolyzed water to reduce foodborne pathogens and spoilage microorganisms on fresh-cut kale. J. Food Sci. 2015, 80, M1277-M1284. [CrossRef]

40. Forghani, F.; Eskandari, M.; Oh, D.H. Application of slightly acidic electrolyzed water and ultrasound for microbial decontamination of kashk. Food Sci. Biotechnol. 2015, 24, 1011-1016. [CrossRef]

41. Green, A.; Popović, V.; Pierscianowski, J.; Biancaniello, M.; Warriner, K.; Koutchma, T. Inactivation of Escherichia coli, Listeria and Salmonella by single and multiple wavelength ultraviolet-light emitting diodes. Innov. Food Sci. Emerg. Technol. 2018, 47, 353-361. [CrossRef]

42. Birmpa, A.; Sfika, V.; Vantarakis, A. Ultraviolet light and ultrasound as non-thermal treatments for the inactivation of microorganisms in fresh ready-to-eat foods. Int. J. Food Microbiol. 2013, 167, 96-102. [CrossRef] [PubMed]

43. Piyasena, P.; Mohareb, E.; McKellar, R.C. Inactivation of microbes using ultrasound: A review. Int. J. Food Microbiol. 2003, 87, 207-216. [CrossRef]

44. Scherba, G.; Weigel, R.M.; O’Brien, W.D. Quantitative assessment of the germicidal efficacy of ultrasonic energy. Appl. Environ. Microbiol. 1991, 57, 2079-2084. [CrossRef] [PubMed]

45. Crook, J.A.; Rossitto, P.V.; Parko, J.; Koutchma, T.; Cullor, J.S. Efficacy of ultraviolet (uv-c) light in a thin-film turbulent flow for the reduction of milkborne pathogens. Foodborne Pathog. Dis. 2015, 12, 506-513. [CrossRef]

46. Adhikari, A.; Syamaladevi, R.M.; Killinger, K.; Sablani, S.S. Ultraviolet-C light inactivation of Escherichia coli O157: H7 and Listeria monocytogenes on organic fruit surfaces. Int. J. Food Microbiol. 2015, 210, 136-142. [CrossRef] [PubMed] 
47. Kim, H.J.; Tango, C.N.; Chelliah, R.; Oh, D.H. Sanitization efficacy of slightly acidic electrolyzed water against pure cultures of Escherichia coli, Salmonella enterica, Typhimurium, Staphylococcus aureus and Bacillus cereus spores, in comparison with different water hardness. Sci. Rep. 2019, 9, 1-14. [CrossRef]

48. Khayankarn, S.; Uthaibutra, J.; Setha, S.; Whangchai, K. Using electrolyzed oxidizing water combined with an ultrasonic wave on the postharvest diseases control of pineapple fruit cv. "Phu Lae". Crop Prot. 2013, 54, 43-47. [CrossRef]

49. Rezende, A.C.B.; Igarashi, M.C.; Destro, M.T.; Franco, B.D.G.M.; Landgraf, M. Effect of gamma radiation on the reduction of Salmonella strains, Listeria monocytogenes, and Shiga toxin-producing Escherichia coli and sensory evaluation of minimally processed spinach (Tetragonia expansa). J. Food Prot. 2014, 77, 1768-1772. [CrossRef]

50. Sommers, C.; Rajkowski, K.T.; Scullen, O.J.; Cassidy, J.; Fratamico, P.; Sheen, S. Inactivation of Shiga Toxin-Producing Escherichia coli in lean ground beef by gamma irradiation. Food Microbiol. 2015, 49, 231-234. [CrossRef] [PubMed]

51. Ghazala, I.; Sila, A.; Frikha, F.; Driss, D.; Ellouz-Chaabouni, S.; Haddar, A. Antioxidant and antimicrobial properties of water soluble polysaccharide extracted from carrot peels by-products. J. Food Sci. Technol. 2015, 52, 6953-6965. [CrossRef]

52. Misic, D.; Tadic, V.; Korzeniowska, M.; Nisavic, J.; Aksentijevic, K.; Kuzmanovic, J.; Zizovic, I. Supercritical fluid extraction of celery and parsley fruit-chemical composition and antibacterial activity. Molecules 2020, 25, 3163. [CrossRef] [PubMed]

53. Koide, S.; Shi, J. Microbial and quality evaluation of green peppers stored in biodegradable film packaging. Food Control 2007, 18, 1121-1125. [CrossRef]

54. Pinheiro, J.; Alegria, C.; Abreu, M.; Gonçalves, E.M.; Silva, C.L.M. Kinetics of changes in the physical quality parameters of fresh tomato fruits (Solanum lycopersicum, cv. 'Zinac') during storage. J. Food Eng. 2013, 114, 338-345. [CrossRef]

55. Pinheiro, J.C.; Alegria, C.S.M.; Abreu, M.M.M.N.; Gonçalves, E.M.; Silva, C.L.M. Evaluation of alternative preservation treatments (water heat treatment, ultrasounds, thermosonication and UV-C Radiation) to improve safety and quality of whole tomato. Food Bioprocess Technol. 2016, 9, 924-935. [CrossRef]

56. Promyou, S.; Supapvanich, S. Effect of ultraviolet-C (UV-C) illumination on postharvest quality and bioactive compounds in yellow bell pepper fruit (Capsicum annuum L.) during storage. Afr. J. Agric. Res. 2012, 7, 4084-4096.

57. Duarte, A.L.A.; do Rosário, D.K.A.; Oliveira, S.B.S.; de Souza, H.L.S.; de Carvalho, R.V.; Carneiro, J.C.S.; Silva, P.I.; Bernardes, P.C. Ultrasound improves antimicrobial effect of sodium dichloroisocyanurate to reduce Salmonella Typhimurium on purple cabbage. Int. J. Food Microbiol. 2018, 269, 12-18. [CrossRef]

58. Esua, O.J.; Chin, N.L.; Yusof, Y.A.; Sukor, R. Combination of ultrasound and ultraviolet-C irradiation on kinetics of color, firmness, weight loss, and total phenolic content changes in tomatoes during storage. J. Food Process. Preserv. 2019, 43, e14161. [CrossRef] 